\title{
PREVALENCE OF EGFR, KI-67, NF-KB, MA-1 MARKER IN CLEFT AFFECTED TISSUE OF SOFT PALATE
}

\author{
Jonas Tellermann ${ }^{1}$, Sophie Charlotte Reiser ${ }^{1}$, \\ Mara Pilmane ${ }^{1,2}$ \\ ${ }^{1}$ Riga Stradiņš University, Riga, Latvia \\ ${ }^{2}$ Department of Morphology, Institute of Anatomy and Anthropology, Riga, Latvia
}

\begin{abstract}
Introduction. Midline orofacial defects bear a high degree of morbidity for the affected individual, often associated with retardation in neonatal development and the need for surgical intervention. The etiology of the deformities, despite their high prevalence, remains, however, largely unknown. We report on the evaluation and quantification of proliferative and inflammatory markers in the cleft affected soft palate.

Material and methods. This study included soft palate samples of eight cleft lip and palate affected individuals and a control group of six soft tissue specimens obtained during correctional surgery of hyperdentia. All samples were processed via immunohistochemistry for marker EGFR, NF- $\mathrm{B}, \mathrm{Ki}-67, \mathrm{Ma}-1$. The results were evaluated semi-quantitatively and statistically analysed by IBM SPSS 25.0.
\end{abstract}

Results. Histopathological signs of inflammatory changes were continuous in cleft affected specimen. The quantitative distribution of the markers in the cleft affected group displayed a significant correlation between EGFR, Ki-67 and NF- $\kappa B(p<0.05)$, along with a correlation among Ki-67 and NF- $\kappa B$ $(\mathrm{p}<0.05)$. Immunoreactive structures in control group showed lower numbers in all evaluated specimen. A statistical significance between cleft affected and non-cleft tissue was observed in EGFR and Ma-1 ( $<<0.05)$.

Conclusion. Results are suggestive of a tissue phenotype modification in cleft affected palate. Observation of distribution and statistical correlation hint towards the involvement of epithelial growth inducer EGFR and inflammatory/proliferative marker in epithelial changes.

Keywords: cleft palate; growth factor; inflammation; proliferation 


\section{INTRODUCTION}

As of today, cleft lip and palate (CLP) are among the most common congenital orofacial abnormalities in the world. Patients often suffer from great discomfort during speech, swallowing and normal feeding [1]. While reports on incidence vary based on ethnicity and socioeconomic status, the prevalence among European-derived populations shows a rate of 1 in 1000 live births [2]. A similar account of affected individuals has been reported in Latvia [3]. Heterogeneous in nature, the etiology of CLP is believed to be the result of multiple genetic and environmental insults [4]. The process of palatogenesis is initiated at embryonic week 5 . Medial nasal processes merge, forming the primary palate, lip and anterior incisors. Events during the secondary palate development span the outgrowth of palatal shelfs (PS) and vertical repositioning with the subsequent elevation of palate. Complete fusion along midline at week 12 is achieved by approximation of PS medial edge epithelial (MEE) cells and formation of medial epithelial seam (MES) [5].

Although resolution of MES is widely accepted, its underlying mechanism is still subject to controversy. Theories currently proposed by the scientific community include cell mediated death, the migration of cells towards nasal or oral epithelium and epithelial-mesenchymal transition [6]. Disruptive events during any step of palatogenesis but prominently during midline fusion, PS formation or elevation bear potential risk for an isolated defect in cleft palate or combined cleft palate/lip defects. A great number of genes is involved in the proliferative phases of embryonic development. Coordinated events among spatial and temporal developmental factors are crucial. While growth factors are common inductors of proliferation, cytokines induced by inflammatory cells are deemed to be determinative in proliferative events and indicative of embryopathic stress [7].

The epidermal growth factor (EGF) belongs to the first group of growth factors identified [8]. Consisting of 53 amino acids [9] and characterized by the ability to promote cell proliferation, growth, differentiation and inhibition of apoptosis, EGF has effects on epithelial, mesenchymal and tumour cells [10, $11,12]$. Tsang et al. (2003) have described the expression of EGF in wound healing, affecting fibroblast motility and granulation tissue formation [13]. As a prototypical ligand, EGF activates EGF receptors (EGFR). EGFR is a transmembrane tyrosine kinase receptor and dimerization can activate downstream signalling pathways including Janus kinase/signal transducer and activator of transcription pathways, mitogen-activated protein kinase and phosphatidylinositol 3-kinase pathways [14]. 
In the developing palate, EGF and EGFR are mainly expressed in the proliferating MEE of developing palates. Exogenous EGF leads to correction to persistent activation of the EGF signalling pathway, resulting in excess proliferation of the MEE cells and prevention of palatal fusion [10].

First described in 1983 [15], the antigen Ki-67 has been an important marker in determining the growth fraction of a given cell population. Present in cell nucleus at all stages of cell cycle (G1, S, G2, M), the marker is not expressed in quiescent G0 cells or cells about to enter the $G$ phase [16]. The role of Ki-67 in human embryonal palatogenesis has not been subject to extensive research [17]. A small number of studies performed on human foetuses state that tissue proliferation gradually decreases towards the end of palatal fusion, with Vukojevic et al. (2012) describing peak intensity during the $6^{\text {th }}$ developmental week $[17,18]$. Insults during any stage of proliferative phase are expected to be a contributory factor towards facial dysmorphia [19].

Nuclear factor-kB (NF- $\mathrm{kB})$ represents a family of inducible transcription factors (TF) most prominently known for their involvement in proinflammatory settings, immune response, tissue proliferation and apoptosis [19]. However, the specific biological effect of NF- $\mathrm{KB}$ induced TFs appears to vary in the context of different cell types and tissue structures. While NF- $\kappa \mathrm{B}-$ induced genes cause inhibition of growth in keratinocytes, they favour proliferation in fibroblasts. The marked differentiation in effects highlights the potential role of NF- $\kappa \mathrm{B}$ in epidermal and dermal cells [20]. Observation of spatiotemporal expression of NF- $\mathrm{BB}$ in embryogenesis of mice noted the first appearance of NF- $\kappa B$ in embryonic day 12.5 , markedly in the embryonic brain and thymus. The study concluded that NF- $\kappa B$ expression is limited to late stages of mammalian development [21]. The significance of the functional role of NF- $\kappa B$ in embryonic development became evident in a study of knockout mice which lacked key components of NF- $\kappa \mathrm{B}$ pathway and displayed high rates of embryonic lethality [22].

Macrophages are innate immune cells displaying functional heterogeneity [23]. Tissue macrophages or monocyte-derived recruited cells in the inflammation process produce host protection by phagocytosis and cytokine secretion [24]. Macrophages can be classified as classically activated macrophages (M1) or alternatively activated macrophages(M2). M1 macrophages are characterized by their pro-inflammatory phenotype [25].

The main stimuli for M1 macrophages are interferon- $\gamma$, lipopolysaccharide and granulocyte macrophage colony-stimulating factor [26, 27]. Reported features of M1 macrophages include antigen presentation, the production of 
interleukin (Il)-1 beta, Il-6, IL-12, Il-18, IL-23, tumour necrosis factor-alpha and the production of nitric oxide and reactive oxygen intermediates [28, 29]. Activation of M1 macrophages can cause chronic inflammation and tissue damage [30].

The aim of this study was the research of cleft affected palate in infants with regard to appearance of inflammatory factors, and distribution of growth and proliferative tissue factors.

\section{MATERIAL AND METHODS}

The research included eight CLP affected patients ranging in age from 3 months to 36 months. Five patients were affected by unilateral CLP and three patients by bilateral CLP. Tissue samples of soft palate were obtained during surgical correction of the cleft in the Cleft Lip and Palate Centre at the Institute of Stomatology of Riga Stradinšs University. The control group included six samples of soft tissues obtained during surgery correcting the state of hyperdentia. There were no associations with CLP, inflammation or any other pathology. The control group participants were aged from 6 to 15 years.

The study was independently reviewed and approved by the local Ethical Committee of Riga Stradiňš University (2003; 2013), and written informed consent was obtained from all parents after explanation of the nature of this study.

Tissue samples were fixed for a day in a mixture of $2 \%$ formaldehyde and $0.2 \%$ picric acid in $0.1 \mathrm{M}$ phosphate buffer ( $\mathrm{pH} 7.2$ ). Following, they were rinsed in thyroid buffer, containing $10 \%$ saccharose for 12 hours, then the samples were embedded into paraffin. 3 micrometre thick sections were cut and coloured with hematoxylin and eosin (H\&E) for subsequent evaluation.

HiDef Detection HRP Polymer system (Cell MARQUE) was used to detect EGFR (code sc-71034, mouse monoclonal antibody, working dilution 1:100, Santa Cruze Biotechnology, USA), Ki-67 (code 1508202A, rabbit monoclonal antibody, working dilution 1:100, Sigma-Aldrich, US), NF-кB (code ab7971, rabbit polyclonal antibody, working dilution: 1:100, Abcam, UK), Ma-1 (code ab9675, rabbit polyclonal antibody, working dilution 1:100, Abcam, UK).

The number of immunopositive structures was graded semi-quantitatively. The scale from " 0 " to " +++ " was used as following: " 0 " - no immunoreactive structures seen in the visual field, " $0 /+$ " - occasional immunoreactive structures seen in the visual field, " + " - few immunoreactive structures seen in the visual field, , "++" - a moderate number of immunoreactive structures seen 
in the visual field, “ +++ " - numerous immunoreactive structures seen in the visual field [31].

The images of specimens were captured by using a Leica camera model DFC 450, and image processing was realized using Image Pro Plus 6.0 software (Media Cybernetics, Silver Spring, Maryland, USA).

Statistical analysis was performed using IBM SPSS version 25.0. The results included calculation of Spearman's rank correlation coefficient $\left(r_{s}\right)$; nonparametric Mann-Whitney U test was used to compare both study groups. Statistical significance was assumed if $\mathrm{p}<0.05$.

\section{RESULTS}

Routinely stained slides displayed mainly parakeratotic invaginated epithelium into underlying connective tissue, with basal cell proliferation and patchy distribution of thickened basement membrane. Superficial epithelial cells showed varying degrees of vacuolization (Fig.1). Underlying subepithelium demonstrated consistent inflammatory infiltrate with extension of lymphocytes into epithelial layer, while connective tissue showed macrophage predominance (Fig. 2). Sclerotic changes of blood vessels, neoangiogenesis and granulation tissue were detected.

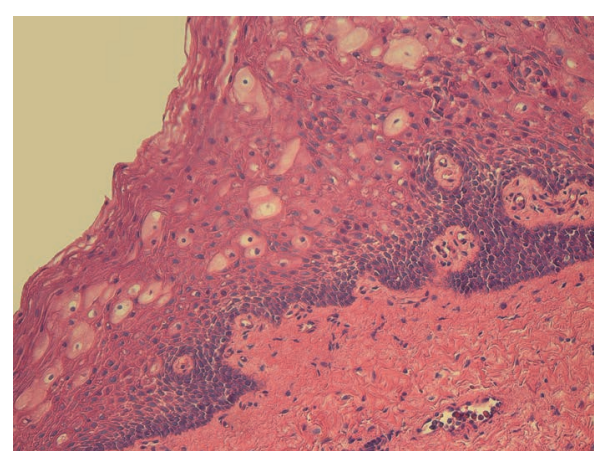

Figure 1. Perinuclear vacuolization and proliferating basal epitheliocytes in cleft affected tissue of soft palate. $H \& E, \times 200$.

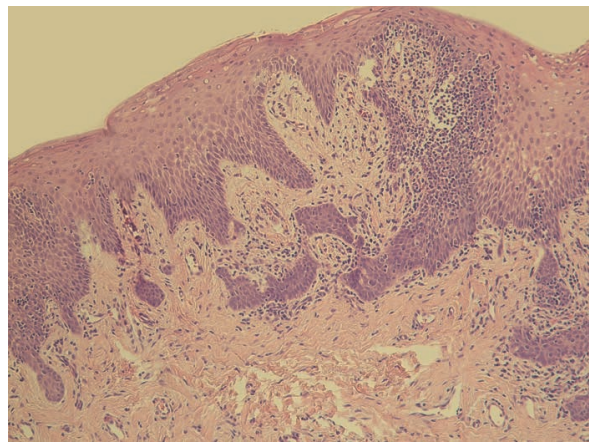

Figure 2. Invaginations of epithelium into underlying connective tissue, proliferating basal epitheliocytes and intraepithelial inflammatory cells in cleft affected tissue of soft palate. $H \& E, \times 100$. 
Table 1. Relative number of tissue factor-containing positive structures in cleft lip palate affected specimen.

\begin{tabular}{llcccccc}
\hline & & & & & \multicolumn{2}{c}{ NF-KB } & \\
\cline { 7 - 8 } Nr. & Gender & Age (Months) & EGFR & Ki-67 & Ep & Subep & Ma-1 \\
\hline 1. & Male & 3 & +++ & +++ & + & ++ & $++{ }^{*}$ \\
\hline 2. & Male & 4 & +++ & ++ & + & +++ & ++ \\
\hline 3. & Male & 4.5 & + & $0 /+\mathrm{P}$ & 0 & $0 /+$ & ++ \\
\hline 4. & Male & 8 & +++ & ++ & $0 /+$ & ++ & ++ \\
\hline 5. & Male & 9 & + & 0 & + & + & $+{ }^{*}$ \\
\hline 6. & Male & 10 & + & 0 & $0 /+$ & $0 /+$ & ++ \\
\hline 7. & Male & 10 & $\mathrm{X}$ & $\mathrm{X}$ & $\mathrm{X}$ & $\mathrm{X}$ & $+{ }^{*}$ \\
\hline 8. & Male & 36 & ++ & $+\mathrm{P}$ & 0 & + & ++ \\
\hline$X$
\end{tabular}

$X=$ no evaluation possible due to insufficient tissue material; $P=$ patchy distribution; ${ }^{*}$ other cells (lymphocytes, fibroblasts)

Table 2. Relative number of tissue factor-containing structures in control group.

\begin{tabular}{lllcccc}
\hline Nr. & Gender & Diagnosis & Ki-67 & NFKB & Ma-1 & EGFR \\
\hline 1. & Male & Hyperdentia & 0 & + & $0 /+$ & 0 \\
\hline 2. & Female & Hyperdentia & 0 & + & $0 /+$ & $0 /+$ \\
\hline 3. & Female & Hyperdentia & 0 & $X$ & $0 /+$ & + \\
\hline 4. & Male & Hyperdentia & + & $X$ & $0 /+$ & $0 /+$ \\
\hline 5. & Female & Hyperdentia & $0 /+$ & + & + & ++ \\
\hline 6. & Female & Hyperdentia & 0 & $\mathrm{X}$ & $0 /+$ & + \\
\hline
\end{tabular}

$X=$ insufficient tissue material

\section{EGFR}

Expression of EGFR in the epithelium was detected in seven specimens (out of eight). EGFR positive cells in the epithelium ranged from few $(+)$ to numerous $(+++)$ (Fig. 3).

A statistically significant correlation was observed between EGFR and Ki-67 positive stained cells $\left(\mathrm{r}_{\mathrm{s}}=0.943 ; \mathrm{p}<0.05\right)$, as well as NFKB $\left(\mathrm{r}_{\mathrm{s}}=0.912 ; \mathrm{p}<0.05\right)$. Overall, the number of EGFR positive cells was lower in control specimens, varying from no positive (0) to moderate $(++)$ positive cells (Fig. 4). The difference of EGFR positive cells was statistically significant $(\mathrm{z}=-2.150, \mathrm{p}=0.032)$ when the CLP group and the control group were compared. 


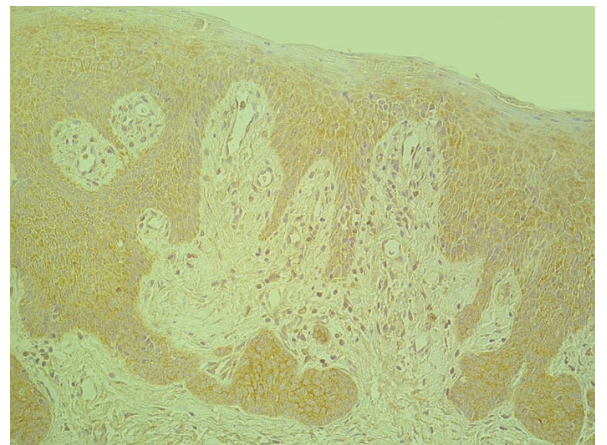

Figure 3. Numerous EGFR positive epitheliocytes in tissue of cleft affected soft palate. EGFR Immunohistochemistry (IHC), ×200.

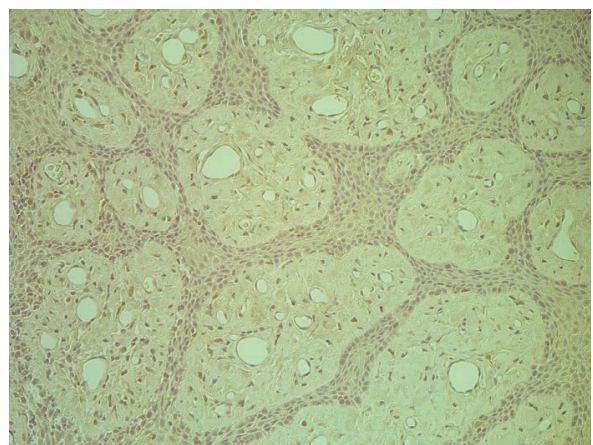

Figure 4. Few EGFR positive epitheliocytes in control specimen. EGFR IHC, $\times 250$.

\section{Ki -67}

Ki-67 appearance was variable. While four samples displayed a moderate $(++)$ number of positive cells, sporadic patchy positive cell clusters were found in two specimens. Absence of any Ki-67 positivity was seen in the remaining two samples.

Prominent expression of Ki-67 showed limitation towards basal and suprabasal epithelial cell layer with marked absence in superficial layers (Fig. 5).

The correlation between Ki-67 and NF- $\kappa \mathrm{B}$ showed statistical significance $\left(\mathrm{r}_{\mathrm{s}}=0.794 ; \mathrm{p}<0.05\right)$.

The control group showed occasional $(0 /+)$ to few $(+)$ positive tissue structures, with a lower number of overall positively stained cells compared to CLP affected samples (Fig. 6).

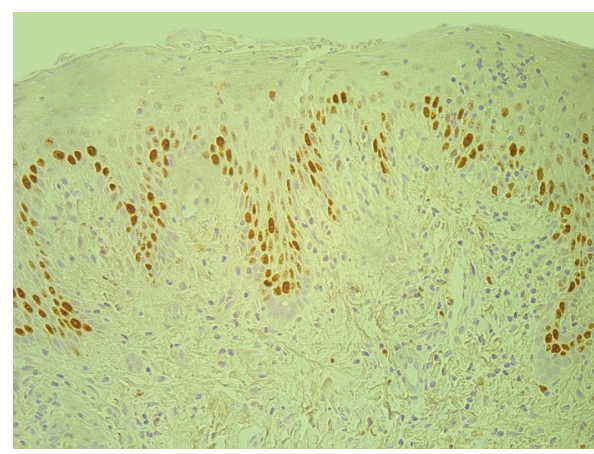

Figure 5. Moderate Ki-67 immunoreactive cells with limitation towards basal and suprabasal epithelial layers in cleft affected soft palate. Ki-67 IHC, $\times 250$.

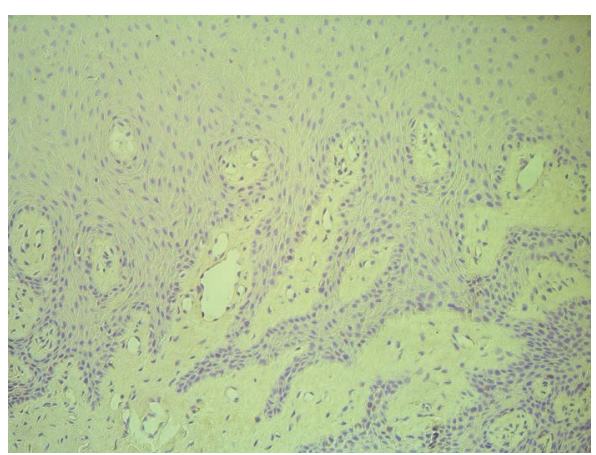

Figure 6. Absence of Ki-67 positive cells in control specimen. Ki-67 IHC, $\times 200$. 


\section{Ma-1}

Ma-1-positive cells ranged from few $(+)$ to moderate $(++)$ (Fig.7). Ma1 -positive cells in the connective tissue included macrophages, lymphocytes and fibroblasts in three cases. The control group samples showed mainly an occasional $(0 /+)$ number of Ma-1-positive cells. Comparison of the number of Ma-1-positive cells of the CLP affected group to the control group showed statistical significance $(\mathrm{z}=-3.091, \mathrm{p}=0.002)$.

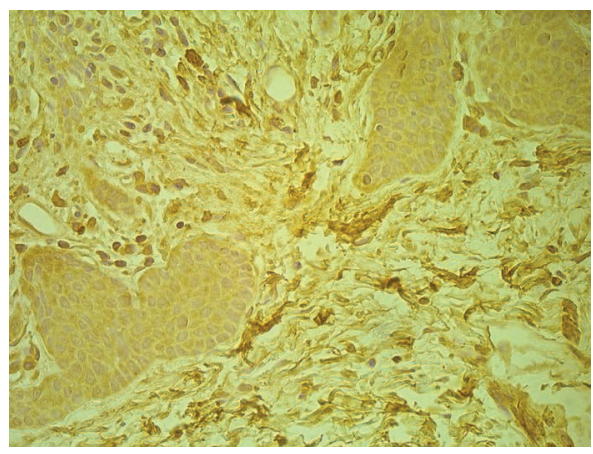

Figure 7. Moderate number of Ma-1 positive cells in the connective tissue of cleft affected soft palate. Ma-1 IHC, $\times 400$.

\section{$N F-\kappa B$}

NF- $\kappa B$ stained tissue samples demonstrated a continuous expression of positive structures, ranging from few $(+)$ to moderate $(++)$ (Fig. 8). Sporadic appearance of positive intraepithelial lymphocytes with abundantly stained subepithelial inflammatory infiltrate was presented in the majority of samples. The control group showed the presence of few $(+)$ positive structures in all samples (Fig. 9).

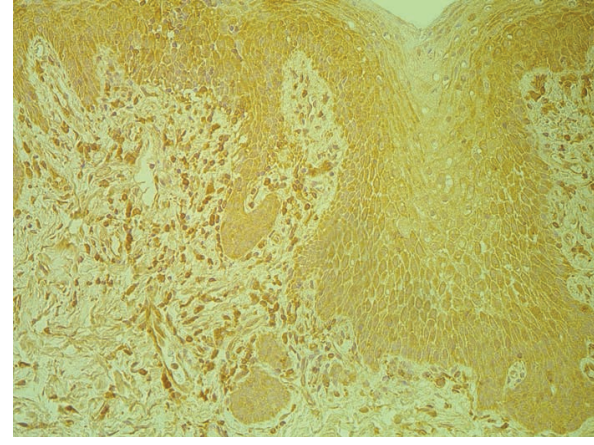

Figure 8. Moderate number of NF-KB positive cells in cleft palate specimen, cells are largely lymphocytes plasma cells, most concentrated in between epithelial folds. NFKB $\mathrm{IHC}, \times 200$.

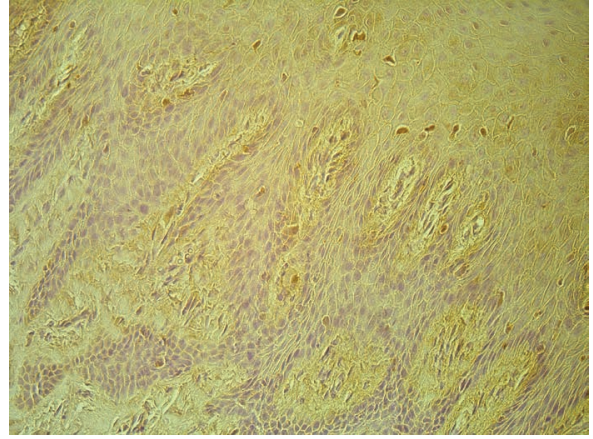

Figure 9. Few NF-KB immunoreative structures in control specimen, occasional pronounced intraepithelial lymphocytes. NFKB IHC, $\times 250$. 


\section{DISCUSSION}

The histological examination and immunohistological reports of cleft affected soft palate tissue proposes a rare entity. The obtained histological data displayed consistent mild to moderate chronic inflammatory changes in all cleft affected individuals. Considering the abnormal anatomical configuration of cleft soft palate, persistent mechanical stress may propose a stimulation for subsequent soft tissue inflammation. The observance of palatal ulceration in CLP affected infants through tongue motor activity largely supports this hypothesis [32]. An isolated report on the histological evaluation of cleft palate demonstrated similar findings of inflammatory infiltrate congruent to our observation [33]. Inflammatory changes proposed major difference compared to non-cleft subjects. In evaluation of proliferative marker Ki-67, there seemed to be no disturbances in spatial distribution comparable to our observation; proliferative activity in normal mucosa appears to be limited to basal and suprabasal cell layers [34]. However, the significantly higher number of Ki-67 immunoreactive cells in cleft individuals compared to the control group remains suggestive of the intensification of proliferative changes in CLP affected epithelium. As data shows a correlation between Ki-67 and NF- $\kappa B$, one can assume that Ki-67 positive cellular proliferation is induced by NF- $\kappa B$. Yan et al. (2014) proposed a model that linked epidermal hyperproliferation in psoriasis to induction of NF- $\kappa \mathrm{B}$ [35]. It remains to be investigated if the model is transferable to oral mucosa; our correlation stands as a unique observance so far. Our work is implicative of a correlation between inflammation and epidermal proliferation. It is, however, of different nature than the ones which have been described before.

Early works on oral mucosa proliferation propose an inverse relationship between intensity of inflammation and proliferation of epithelial cells [36]. A report on radicular cyst even noted a higher Ki-67 epithelial expression in absence of intense inflammatory infiltrate [37].

We, however, cannot currently confirm that assumption, as our results suggest a positive correlation between the inflammatory marker NF- $\kappa \mathrm{B}$ and Ki-67.

Fernandez et al. (2017) reported the presence of EGFR in normal oral mucosa, indicative of the proliferation of epithelial cells. Receptors were found to be not only limited to basal stratum cells but were also expressed by suprabasal cells [38]. Similar findings regarding the distribution of EGFR immunoreactive epithelial cells were observed in soft tissues of the control group and in CLP affected tissues in our patients. Apart from EGFRs role in tissue homeostasis, aberrant receptor activation is affecting carcinogenesis, including 
carcinogenesis of head and neck squamous cell carcinomas [39]. Increased proliferation of epithelial cells has also been observed in hyperproliferative skin diseases such as psoriasis vulgaris and seborrheic keratosis where upregulation of EGFR or its ligands has been described [40]. Therefore, we can assume that an overall increase in numbers of EGFR, as observed in CLP affected tissue, might demonstrate increased proliferation in those epithelia. This could be indicative of the phenotypical changes observed in the epithelium of CLP affected soft palate tissue. Identification of EGFR in repairing burn wound epithelial margins suggests that the presence of EGFR is a common denominator in the wound healing process after burn injury [41]. When a mouse spontaneous colitis model was used, mice with defective EGFR activity were more susceptible to experimental colitis [42]. CLP affected tissues demonstrated higher numbers regarding the presence of EGFR immunoreactive epithelial cells and Ma-1-positive cells, mainly macrophages. Lymphocytes and fibroblasts have also been noted in subepithelial connective tissue. Observation of mainly Ma-1-positive macrophages might be an indicator of persistent inflammatory changes observed in CLP affected tissues. The M1 macrophages were characterized by their ability to produce a wide range of pro-inflammatory cytokines and their microbiocidal capacity [28]. Also, the enhancement of NF-kB-dependent gene expression was seen in the classic activation of macrophages [43].

\section{CONCLUSION}

CLP affected palate shows variations of epithelium basal part probably due to the tissue phenotype modification with involvement of the epithelial growth inducer EGFR and proliferation marker Ki-67. Induction by inflammation was proved by correlation between Ki67 and inflammation/proliferation marker $\mathrm{NF}-\kappa \mathrm{B}$, and pro-inflammatory macrophages activator Ma-1 might also modify the epithelium in the cleft affected palate.

\section{REFERENCES}

1. Bush J.O., Jiang R. (2012). Palatogenesis: morphogenetic and molecular mechanisms of secondary palate development. Development, 139, 2, 231-43. https://doi.org/10.1242/dev.067082

2. Dixon M.J., Marazita M.L., Beaty T.H., Murray J.C. (2011). Cleft lip and palate: understanding genetic and environmental influences. Nat Rev Genet, 12, 167-178. https://doi.org/10.1038/nrg2933 
3. Akota I., Barkane B., Grasmane N. (2000). The incidence of cleft lip and/or palate (CLP) in Latvia during years 1960 to 1997. J Craniomaxillofac Surg, 28, Suppl.1, 3 .

4. Parada C., Chai Y. (2012). Roles of BMP Signaling Pathway in Lip and Palate Development. Front Oral Biol, 16, 60-70. https://doi.org/10.1159/000337617

5. Gritli-Linde A. (2007). Molecular control of secondary palate development. Dev Biol, 301, 309-326. https://doi.org/10.1016/j.ydbio.2006.07.042

6. Vaziri Sani F., Hallberg K., Harfe B.D., McMahon A.P., Linde A., Gritli-Linde A. (2005). Fate-mapping of the epithelial seam during palatal fusion rules out epithelial-mesenchymal transformation. Dev Biol, 15, 285(2), 490-5. https://doi.org/10.1016/j.ydbio.2005.07.027

7. Torchinsky A., Toder V. (2004). To Die or Not to Die: The Function of the Transcription Factor NF-jB in Embryos Exposed to Stress. Am J Reprod Immunol, 51, 2, 138-143. https://doi.org/10.1046/j.8755-8920.2003.00134.x

8. Cohen S. (1962). Isolation of a mouse submaxillary gland protein accelerating incisor eruption and eye-lid opening in the new-born animal. J Biol Chem, 237, $1555-1562$.

9. Taylor J.M., Mitchell W.M., Cohen S. (1972). Epidermal growth factor: Physical and chemical properties. J Biol Chem, 247, 5928-5934.

10. Abbott B.D., Adamson E.D., Pratt R.M. (1988). Retinoic acid alters EGF receptor expression during palatogenesis. Development, 102, 853-867.

11. Zhang L., Zhang J., Chen Z., Wang L., Wu X., Ou M. (2016). Epidermal growth factor (EGF) triggers the malignancy of hemangioma cells via activation of NF- $\mathrm{kB}$ signals. Biomedicine \& Pharmacotherapy, 82, 133-140. https://doi.org/10.1016/j.biopha.2016.05.002

12. Kim D., Kim S.Y., Mun S.K., Rhee S., Kim B.J. (2015). Epidermal growth factor improves the migration and contractility of aged fibroblasts cultured on 3D collagen matrices. International Journal of Molecular Medicine, 35, 1017-1025. https://doi.org/10.3892/ijmm.2015.2088

13. Tsang M.W., Wong W.K.R., Hung C.S., Lai K.M., Tang, W. Cheung E.Y.N., Kam G., Leung L., Chan C.W., Chu C.M. (2003). Human epidermal growth factor enhances healing of diabetic foot ulcers. Diabetes care, 26, 1856-1861. https://doi.org/10.2337/diacare.26.6.1856

14. Wee P., Wang Z. (2017). Epidermal Growth Factor Receptor Cell Proliferation Signaling Pathways. Cancers, 9(5), 52. https://doi.org/10.3390/cancers 9050052

15. Gerdes J., Schwab U., Lemke H., Stein H. (1983). Production of a mouse monoclonal antibody reactive with a human nuclear antigen associated with cell proliferation. Int J Cancer, 31, 13-20. https://doi.org/10.1002/ijc.2910310104

16. Gerdes J., Lemke H., Baisch H., Wacker H.H., Schwab U., Stein H. (1984). Cell cycle analysis of a cell proliferation-associated human nuclear antigen defined by the monoclonal antibody Ki-67. J Immunol, 133, 1710-1715. 
17. Vukojevic K., Kero D., Novakovic J., Kalibovic Govorko D., Saraga-Babic M. (2012). Cell proliferation and apoptosis in the fusion of human primary and secondary palates. Eur J Oral Sci, 120, 283-291.

https://doi.org/10.1111/j.1600-0722.2012.00967.x

18. Cox T.C. (2004). Taking it to the max: The genetic and developmental mechanisms coordinating midfacial morphogenesis and dysmorphology. Clin Genet, 65, 163-176. https://doi.org/10.1111/j.0009-9163.2004.00225.x

19. Seitz C.S., Lin Q., Deng H., Khavari P.A. (1998). Alterations in NF-kappaB function in transgenic epithelial tissue demonstrate a growth inhibitory role for NF-kappaB.; Proc Natl Acad Sci U S A, 95, 5, 2307-12. https://doi.org/10.1073/pnas.95.5.2307

20. Hinata K., Gervin A.M., Jennifer Zhang Y., Khavari P.A. (2003). Divergent gene regulation and growth effects by NF-kappa B in epithelial and mesenchymal cells of human skin. Oncogene, 22, 13, 1955-64.

https://doi.org/10.1038/sj.onc.1206198

21. Schmidt-Ullrich R., Mémet S., Lilienbaum A., Feuillard J., Raphaël M., Israel A. (1996). NF-kappaB activity in transgenic mice: developmental regulation and tissue specificity. Development, 122, 7, 2117-28.

22. Beg A.A., Sha W.C., Bronson R.T., Ghosh S, Baltimore D. (1995). Embryonic lethality and liver degeneration in mice lacking the RelA component of NF-kappa B. Nature, 376, 6536, 167-70. https://doi.org/10.1038/376167a0

23. Mills C.D., Ley K. (2014). M1 and M2 macrophages: the chicken and the egg of immunity. J Innate Immun, 6, 6,716-726. https://doi.org/10.1159/000364945

24. Geissmann F., Manz M.G., Jung S., Sieweke M.H., Merad M., Ley K. (2010). Development of monocytes, macrophages, and dendritic cells. Science, 327, 656-661. https://doi.org/10.1126/science.1178331

25. Mantovani A., Sica A., Sozzani S., Allavena P., Vecchi A., Locati M. (2014). The chemokine system in diverse forms of macrophage activation and polarization. Trends Immunol, 25, 677-86. https://doi.org/10.1016/j.it.2004.09.015

26. Martinez F.O., Gordon S. (2014). The M1 and M2 paradigm of macrophage activation: time for reassessment. F1000prime reports, 6, 13.

https://doi.org/10.12703/P6-13

27. Lacey D.C., Achuthan A., Fleetwood A.J., Dinh H., Roiniotis J., Scholz G.M., Chang M.W., Beckman S.K., Cook A.D. Hamilton J.A. (2012). Defining GMCSF- and macrophage-CSF-dependent macrophage responses by in vitro models. J Immunol,188, 5752-5765. https://doi.org/10.4049/jimmunol.1103426

28. Verreck F.A., de Boer T., Langenberg D.M., Hoeve M.A., Kramer M., Vaisberg E., Kastelein R., Kolk A., de Waal-Malefyt R., Ottenhoff T.H. (2004). Human IL-23-producing type 1 macrophages promote but IL-10-producing type 2 macrophages subvert immunity to (myco)bacteria. Proc Natl Acad Sci USA, 101, 13, 4560-4565. https://doi.org/10.1073/pnas.0400983101 
29. Mosser D.M. (2003). The many faces of macrophage activation. J Leukoc Biol, 73, 209-212. https://doi.org/10.1189/jlb.0602325

30. Van den Bossche J., Baardman J., Otto N.A., van der Velden S., Neele A.E., van den Berg S.M., Luque-Martin R., Chen H.J., Boshuizen M.C., Ahmed M., Hoeksema M.A., de Vos A.F., de Winther M.P. (2016). Mitochondrial dysfunction prevents repolarization of inflammatory macrophages. Cell Rep,17, 684-696. https://doi.org/10.1016/j.celrep.2016.09.008

31. Pilmane M., Luts A., Sundler F. (1995). Changes in neuroendocrine elements in bronchial mucosa in chronic lung disease in adults. Thorax, 50, 5, 551-554. https://doi.org/10.1136/thx.50.5.551

32. Bacher M., Göz G., Pham T., Ney T., Ehrenfeld M. (1996). Congenital Palatal Ulcers in Newborn Infants with Cleft Lip and Palate: Diagnosis, Frequency, and Significance. Cleft Palate Craniofac J, 33, 1, 37-42. https://doi.org/10.1597/1545-1569_1996_033_0037_cpuini_2.3.co_2

33. Fisher J.H., Shiere F.R., Berkman M.D., Cataldo E.F., Fogels H.R. (1967). Oral tissue changes in infants with cleft palate. Cleft Palate J, 4, 316-26.

34. Liu S.C., Sauter E.R., Clapper M.L., Feldman R.S., Levin L., Chen S.Y., et al. (1998) Markers of Cell Proliferation in Normal Epithelia and Dysplastic Leukoplakias of the Oral Cavity. Cancer Epidemiol Biomarkers Prev, 7, 597-603.

35. Yan S., Xu Z., Lou F., Zhang L., Ke F., Bai J. et al. (2015) NF-kB-induced microRNA-31 promotes epidermal hyperplasia by repressing protein phosphatase 6 in psoriasis. Nat Commun, 6, 7652. https://doi.org/10.1038/ncomms8652

36. Willoughby S.G., Hopps R.M., Johnson N.W. (1986). Changes in the rate of Epithelial Proliferation of rat oral mucosa in response to acute inflammation induced by turpentine. Archives of Oral Biology, 31, 3, 193-199. https://doi.org/10.1016/0003-9969(86)90127-5

37. Ayoub M.S., Baghdadi H.M., El-Kholy M. (2011). Immunohistochemical detection of laminin-1 and $\mathrm{Ki}-67$ in radicular cyst and keratocystic odontogenic tumors. BMC Clinical Pathol, 11, 4. https://doi.org/10.1186/1472-6890-11-4

38. Fernández A., Fernández J., Marshall M., Martínez R., Niklander S., Haidar Z.S. (2017). Difference in EGFR expression and mean vascular density in normal oral mucosa, oral epithelial dysplasia and oral squamous cell carcinoma. J Oral Res, 6, 2, 39-45. https://doi.org/10.17126/joralres.2017.016

39. Cimpean A.M., Balica R.A., Doros I.C., Balica N.C., Gaje P.N., Popovici R.A., Raica M. (2016). Epidermal Growth Factor Receptor (EGFR) and keratin 5 (K5): versatile keyplayers defining prognostic and therapeutic sub-classes of head and neck squamous cell carcinomas. Cancer Genomics and Proteomics,13, 1, 75-81.

40. Nanney L.B., Ellis D.L., Levine J., King L.E. (1992). Epidermal growth factor receptors in idiopathic and virally induced skin diseases. Am J Pathol, 140, 4, 915-925. 
41. Wenczak B.A., Lynch J.B., Nanney L.B. (1992). Epidermal growth factor receptor distribution in burn wounds. Implications for growth factor-mediated repair. J Clin Invest, 90, 6, 2392-2401. https://doi.org/10.1172/JCI116130

42. Dubé P.E., Yan F., Punit S., Girish N., McElroy S.J. (2012). Epidermal growth factor receptor inhibits colitis-associated cancer in mice. J Clin Invest, 122, 8, 2780-2792. https://doi.org/10.1172/JCI62888

43. Brüne B., Dehne N., Grossmann N., Jung M., Namgaladze D., Schmid T., von Knethen A., Weigert A. (2013). Redox control of inflammation in macrophages. Antioxid Redox Signal, 19, 6, 595-637. https://doi.org/10.1089/ars.2012.4785

\section{Address for correspondence:}

Jonas Tellermann

Matisa iela 133/135

Riga, Latvia

E-mail: J.Tellermann@web.de

Phone: +37120633674 